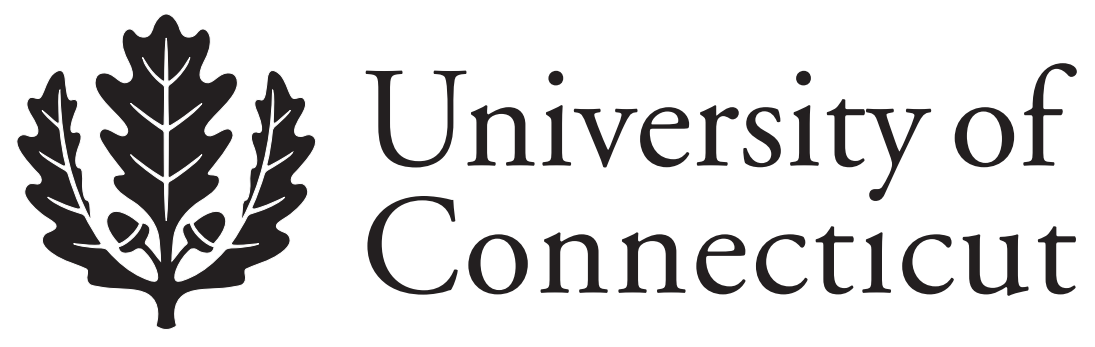

Department of Economics Working Paper Series

The Political Economy of Constitutional Choice: A Study of the 2005 Kenyan Constitutional Referendum

Mwangi S. Kimenyi

University of Connecticut

William F. Shughart II

University of Mississippi

Working Paper 2008-08

March 2008

341 Mansfield Road, Unit 1063

Storrs, CT 06269-1063

Phone: (860) 486-3022

Fax: (860) 486-4463

http://www.econ.uconn.edu/

This working paper is indexed on RePEc, http://repec.org/ 


\begin{abstract}
Recent studies of the linkages between the wealth of nations and the institutions of governance suggest that concentrating political power in a monarchy or a ruling coalition impedes economic growth and, moreover, that while powerdiffusing reforms can enhance the wellbeing of society in general, opposition by groups benefitting from the status quo is predictable. In November 2005, Kenyans rejected a proposed constitution that, despite promises made by their new chief executive, would not have lessened the powers of the presidency. Using a unique, constituency-level dataset on the referendum vote, we estimate a model of the demand for power diffusion and find that ethnic groups' voting decisions are influenced by their expected gains and losses from constitutional change. The results also highlights the importance of ethnic divisions in hindering the powerdiffusion process, and thus establish a channel through which ethnic fragmentation adversely impacts economic development.
\end{abstract}

Journal of Economic Literature Classification: D72

Keywords: Constitutions, Direct Democracy, Public Goods, Interest Groups, Ethnic Divisions.

We benefitted from the comments of participants in economics department seminars at the University of Mississippi, the University of Connecticut and at Oxford University's Center for the Study of African Economies. Thanks to John Colon, Krishna Ladha, Simona Tick, Mark Van Boening, Steve Ross, Christian Zimmermann, Dennis Heffley, Hui-chen Wang and, especially, the Kenyan members of the audience attending a BB\&T Lecture at West Virginia University. Brandon Ramsey's research assistance also is gratefully acknowledged. As is customary, however, the authors nevertheless accept full responsibility for any and all errors. 


\section{The Political Economy of Constitutional Choice: A Study of the 2005 Kenyan Constitutional Referendum}

\section{Introduction}

$\mathrm{O}$

ne of the most significant advances in the economics literature during the past few decades has been to place political and economic institutions at center stage in explaining why some nations are rich while others are poor. The pioneering work of North (1981), North and Thomas (1973), North and Weingast (1989), and Olson (1965, 1982), among others, emphasizes the importance of secure property rights, contract enforcement and the quality of governance in providing the proper incentives for capital accumulation and economic growth. More recent studies by Acemoglu and Robinson (2000a, 2000b) and Acemoglu, Johnson and Robinson (2001, 2005) suggest that sustainable economic progress requires institutional constraints on the authority of the chief executive - or what Powellson (1994) calls diffusion of power. Acemoglu and his colleagues provide evidence showing that concentrating power in a monarchy or a ruling coalition erects a barrier on the path to prosperity (see also Olson 1993, 1997). Leveraging power-sharing reforms is therefore crucial to economic development. Moreover, the extent of power diffusion varies across countries and depends in part on the capacity of marginalized groups to influence institutional change (Powellson 1994).

Acemoglu, Johnson and Robinson (2005) also suggest that while institutional redesign, including reforms that constrain the chief executive's authority, is beneficial to society in general, it will be resisted by groups that stand to lose economic rents or political power. Groups differ in their preferences for institutional change, and in a society where power is not shared widely, those benefiting from the status quo have strong incentives to defend it. We test this theory using voting data from Kenya's 2005 constitutional referendum. Kenya is a typical African country and although it has escaped the military rule and civil war that plague the continent, political authority is 
concentrated to a high degree in the hands of the nation's chief executive. For many years, Kenyans agitated for constitutional change that would lessen that branch's power, but then-President Daniel Arap Moi's regime thwarted the process and blocked the timely adoption of a more democratic constitution.

In December 2002, Kenyans elected a coalition government headed by President Mwai Kibaki, bringing to an end 40 years of rule by the Kenya African National Union (KANU), a party that had dominated politics since independence. The rejection of KANU was the culmination of many years of frustration with leadership characterized by nepotism, corruption, poor economic management and widespread violations of human rights. Misrule under the KANU regime has been attributed to a national constitution that confers too much power on the presidency as well as to the almost complete absence of power separation between the executive, judicial and legislative branches of government. Presidents Moi and Jomo Kenyatta before him used their executive powers to marginalize some ethnic groups and to redistribute the country's resources to reward their political supporters, thereby exacerbating regional and ethnic disparities and also undermining investment incentives (see, for example, Odhiambo 2004). To demonstrate his commitment to advancing democracy in the country, in his inaugural address President Kibaki pledged that a new constitution would be completed within 100 days.

In the event, the process of constitutional reform took much longer than promised; a draft was not completed until late 2005. The delay in finalizing the document's language grew out of what were referred to as "contentious" issues that revolved around the distribution of power between the chief executive and the national legislature. The new constitution was submitted to Kenya's voters for ratification in a national referendum held during November 2005. It was rejected by a landslide of "No" votes. The principal reason for defeat, in the eyes of its opponents, was that the proposed constitution, much like the one it was meant to replace, endowed the executive branch with 
excessive political authority. The majority of voters instead favored a system in which substantial power would be devolved to the national legislature, with a prime minister serving as head of government. Thus, the proposed constitution's failure to deal with the most salient political issue constraining executive power - was the proximate cause of its overwhelming rejection.

Although the proposed Kenyan constitution was defeated soundly nationwide, the numbers of votes cast for and against it varied considerably across the country. The diverse voting patterns observed in Kenya's 210 parliamentary constituencies suggest differences in the perceived benefits and costs associated with approval or disapproval of the new constitution. Voting data from the constitutional referendum and the availability of reasonably good information on the economic and demographic characteristics of voting jurisdictions supply a rare opportunity to evaluate the demand for power diffusion in a developing country setting. Adopting a rational choice framework, we present empirical results that are consistent with the theoretical prediction that power diffusion will be opposed by those who benefit from the concentration of power. Our findings also point to the conclusion that ethnicity is a barrier to power diffusion; we are thus able to identify a channel through which ethnic fragmentation negatively impacts economic growth, namely, by slowing the power diffusion process. Section II provides an overview of the November 2005 Kenyan vote and places it in the context of a simple model of constitutional choice. Section III presents the empirical model and results; section IV concludes.

\section{The Demand for Power Diffusion through Constitutional Choice}

Popular referendums, sometimes referred to as direct democracy, are being used with increasing frequency around the globe to decide important public policy issues (Deacon and Shapiro 1975; Matsusaka 1992, 2006; Butler and Austin 1994; Fidrmuc 1998; Coate and Conlin 2004), including whether or not to approve national constitutions and to make choices about regional political and 
economic integration (Clarke and Kornberg 1994; Remmer and Gelineau 2003; Vlachos 2005). Developing countries undergoing democratic transitions have not been immune to this trend. In November 2005, Kenyans voted in a constitutional referendum asking them to accept or reject a proposed constitution which, if approved by the majority of the voters, would have replaced the current constitution. To provide background for our analysis of the factors that influenced Kenyans to vote decisively in favor of the status quo, we start by looking at the regional and ethnic patterns of voting on the constitutional referendum.

\subsection{Voting Patterns}

Kenya is divided into eight main administrative regions, known as provinces (Figure 1), which are in turn divided into 70 subunits called districts. Except for the fairly heterogeneous Nairobi Province, ${ }^{1}$ site of the national capital and the country's most populous urban area, the other provinces are dominated by particular ethnic groups and while not entirely homogenous, comprise people closely related in terms of language and customs. The 70 districts exhibit greater homogeneity in terms of ethnicity, population characteristics and economic activities. Representation in the national parliament is based on constituencies, which are components of the districts. There are presently 210 parliamentary constituencies; these subunits tend to be much more ethnically homogeneous than either the districts or provinces.

Table 1 provides summary information on the results of the constitutional referendum for Kenya as a whole, its eight provinces, 70 districts and principal ethnic groupings. As can be seen, there is considerable variation in the percentages of votes cast in favor of the new constitution. While $38 \%$ of the voters approved it nationwide, $93.28 \%$ voted "Yes" in the Central Province, but only $15.04 \%$ did so in Nyanza Province. A similarly wide variation in voter support is observed at the district level, ranging from $98.39 \%$ in Nyeri to only $0.68 \%$ in Rachuonyo. Differences in the

\footnotetext{
${ }^{1}$ Nairobi Province is not sub-divided into districts. That is, there is only one district also known as Nairobi.
} 
level of support for the new constitution also are evident across ethnic groups: $93.28 \%$ of the Kikuyus favored it, for example, compared with only $1.43 \%$ of the Luos.

Large differences in the percentages of voters who turned out for the constitutional referendum likewise are apparent in the data summarized in Table 1. Turnout nationally was nearly $60 \%$, but it was only $27.26 \%$ in North Eastern Province. The highest voter turnout rate $(71.86 \%)$ occurred in the Rift Valley Province. Voter turnout across the districts ranged from a low of 24.7\% in Mandera, to a high of $84 \%$ in Migori. Among Kenya's main ethnic groups, turnout was highest for the Kikuyus $(72.18 \%)$ and lowest for the Mji Kenda $(40.48 \%) .^{2}$ The last column in Table 1 shows the percentages of votes cast for Mwai Kibaki in the 2002 presidential election. Because he ran for office pledging constitutional reform, but later reneged, our empirical analysis asks whether the outcome of the constitutional referendum can be explained in part by the earlier vote. Did President Kibaki's supporters rally behind the new constitution he offered to the country? Or did they instead vote against it in retaliation for breaking his promise to cede executive power?

Overall, the results of the 2005 referendum suggest that regionalism and ethnicity may be important in explaining constitutional choice in Kenya. The wide variation observed in the percentages of votes cast for and against the proposed constitution points to large differences in the demand for institutional change across regions and ethnic groups. We test whether regionalism and ethnicity are significant determinants of voter choice once we control for other factors, including support for President Kibaki in 2002.

\subsection{Models of Constitutional Choice}

Exit polls confirm that the issue of power diffusion was decisive in determining the outcome of Kenya's constitutional referendum. The majority of the Kenyans who voted against the proposed

\footnotetext{
${ }^{2}$ Voter turnout rates vary because of differences in the cost of voting (e.g., distances to polling stations, weather on Election Day, and the effectiveness of efforts to "get out the vote"). Our study does not attempt to explain why the percentages of Kenyans who went to the polls in November 2005 differed so greatly across provinces, districts and ethnic groups.
} 
constitution said that they did so because, just as in the document it would have replaced, undue political power was vested in the presidency. Its adoption was therefore unlikely to produce gains for groups that had been marginalized under the status quo. Thus, those who voted "No" were expressing a demand for power diffusion while those who supported the new constitution preferred a system that kept power in the hands of the nation's chief executive.

Although concentration of power in the executive branch of government was the most debated issue in the run-up to the constitutional referendum (and its salience is supported by the exit polling data), from a constitutional economics perspective the proposed constitution had other serious flaws. It included, for example, guarantees of so-called economic rights. The inclusion of guarantees that could not be enforced or perhaps even achieved may have been perceived as evidence that the proposed constitution would not impose effective constraints on the central government (Kimenyi 2006). However, neither the opponents nor the supporters of the draft constitution debated its "economic rights" aspects.

Our empirical model accordingly is based on the assumption that voting on the constitutional referendum was determined in large part by differences in the demand for power diffusion. In other words, we interpret the data presented in Table 1 as reflecting differences in the expected gains and losses associated with adoption or rejection of the constitution across the various groups and regions.

The analysis herein thus has much in common with Beard's ([1913] 1986) seminal study of the economic forces that shaped the U.S. Constitution. He contended that the document crafted at Philadelphia took the form it did - and ultimately was ratified - because the interests of merchants, creditors and advocates of "sound" money prevailed over those of farmer-debtors and supporters of cheap paper money. Although Beard's conclusions have been disputed by historians, recent work has restored credibility to his economic interpretation, but also suggests that the interests at play 
were more varied and more nuanced than originally thought (McGuire and Ohsfeldt 1986, 1989, 1997; McGuire 1988, 2003). ${ }^{3}$ Consistent with the modern evidence, we see voting on the proposed Kenyan constitution as being determined primarily by its anticipated effects on Kenyans' economic wellbeing. The regions and ethnic groups that benefited from a constitution that concentrated power in the presidency would therefore have tended to vote "Yes" in order to preserve their previous gains. On the other hand, those who had been left behind under the status quo would have tended either to abstain or to vote "No" because they expected to continue to be marginalized if the proposed constitution was ratified.

In a pluralistic society ruled by a strong chief executive not obliged to share much power with the other branches of government, the groups that prosper are those on which the ruler relies for political support. The members of the supporting coalition are first in line for patronage positions and for government-financed economic development initiatives, such as roads, schools, water-distribution systems and other infrastructure. Cabinet posts in the Kenyan government are dominated by the president's own ethnic group, which serves as the linchpin of his power base (Kimenyi and Shughart 1989). Economic wellbeing is thus linked closely to partisanship and ethnicity.

Ethnicity supplies a natural basis for group formation (Landa 1994). ${ }^{4}$ Ethnic identities frequently are readily ascertainable, thus lowering the cost of distinguishing insiders from outsiders. Shared behavioral norms and repeated interaction facilitate the development of stable trading

\footnotetext{
${ }^{3}$ Also see Landes and Posner (1975), who view the U.S. Constitution as a means of transferring wealth to any group powerful enough to have influenced its design or subsequently to succeed in amending it. Mueller (1997) summarizes the relevant literature.

${ }^{4}$ Individuals identify with a group for many reasons, but one key factor is that the members of a group are by definition participating in a positive-sum game. Cooperation yields benefits in excess of costs which are shared according to some rule. In interacting with other groups, however, the game frequently is zero-sum: one group's gains are secured at other groups' expense. This is especially true when it comes to capturing control of governmental institutions, which are important sources of artificially created scarcity rents. The availability of rents promotes the formation of special-interest groups that compete for access to them (Buchanan 1980). Conflict often is unavoidable because the group that seizes power distributes the rents among it own members and rarely compensates the losers (Hardin 1995).
} 
networks and credit markets. The ability to distinguish and recognize individuals, to reward good behavior and to punish bad, promotes reputation-building, which lowers transaction costs by helping control free-riding (Gifford 2004). Moreover, the imperatives of evolutionary biology survival and reproduction - make it rational for individuals to value the wellbeing of even remote kin over the genetically distinct members of unrelated groups: under the right conditions, the selfish gene can also be a reciprocal altruist (Dawkins 1976).

Ethnicity is vulnerable to exploitation, however. Emphasizing differences and fabricating ethnic tensions nurses the grievances of groups on the margins of social and economic life. Glaeser (2005), for example, presents a model where political entrepreneurs foment hatred of other ethnic groups to build solidarity and organize mass action, including the use of deadly force, to advance their own agendas. Indeed, by posing a credible threat to the existing "government's monopoly power over determination of the distribution of rents" (Kirk 1983), domestic violence directed at other ethnic groups can be a strategic choice for capturing power.

But ethnic diversity does not inevitably produce hostility and civil strife. Collier (2000a), for example, finds that very ethnically heterogeneous countries tend to have lower levels of conflict than those where one ethnic group dominates other minorities. ${ }^{5}$ As a matter of fact, the existing literature concludes that ethnic Balkanization leads to discord and economic stagnation only when "excessive" in-group identification (Sen 2006) is combined with poor institutions of governance. In the context of Africa, Easterly (2000) suggests that good institutions - economic liberties and political rights can overcome the negative effects of ethnic rivalry by enabling the sharing of political power and facilitating inter-group cooperation, hence muting tensions and promoting economic progress. ${ }^{6}$

\footnotetext{
${ }^{5}$ Specifically, in societies where one ethnic group comprises $45-90 \%$ of the population there is a $28 \%$ chance of civil conflict. However, when ethnic groups are more evenly distributed the probability of conflict falls to $3 \%$.

${ }^{6}$ Basuchoudhary and Shughart (2006) report evidence that economic liberties, such as enforcement of contracts, are more important than political rights in reducing the likelihood that an ethnically diverse country will become a staging ground for transnational terrorism.
} 
Our economic interpretation of Kenya's constitutional referendum is buttressed by unconfirmed reports that politicians and businesspeople invested heavily to influence the outcome. Both opponents and supporters of the draft constitution are said to have spent generously to promote their points of view and to turn out the vote on Election Day. We do not have access to detailed information on the sources and uses of these funds, but Table 2 suggests that these efforts varied considerably in effectiveness. The percentage of Kenyans voting "Yes" is positively and significantly correlated with voter turnout rates in two provinces: Coast and East. The correlation is negative and significantly different from zero in the Rift Valley and Nyanza provinces. Among Kenya's main ethnic groups, the percentage of votes cast in favor of the proposed constitution is positive and significant for the Gikuyu, Embus and Merus ("GEMA") and for the Mji Kendas; it is negative and significant for the Luos and the Kalenjins. ${ }^{7}$

In addition to indicating differences both in the effectiveness of campaign spending on voter turnout and in the perceived regional and ethnic impact of constitutional change, the data in Table 2 also help answer an important background question: if the new constitution would have maintained the status quo in terms of presidential power, why did its opponents bother to vote? Given that voters who had been marginalized under the existing constitution plausibly could expect the same treatment under the new one, choosing to stay home on Election Day would allow them to avoid the cost of voting on an issue with no apparent instrumental consequences. Abstention evidently was not an option for large numbers of Luos and Kalenjins, however. Turnout among those two groups as well as in the Rift Valley and Nyanza provinces more generally was driven largely by

\footnotetext{
${ }^{7}$ We also calculated correlations between the percentage of Kenyans voting "Yes" in the constitutional referendum and voter turnout rates at the district level. Generally speaking, however, the number of voting constituencies per district is too small to produce meaningful results. We nevertheless found positive and significant correlations in the Nyeri $\left(r^{2}=\right.$ 0.986, $\mathrm{p}=0.002)$, Kiambu $\left(r^{2}=0.900, \mathrm{p}=0.037\right)$, and Kakamega $\left(r^{2}=0.924, \mathrm{p}=0.076\right)$ districts; the correlations were negative and significant in Meru North $\left(r^{2}=-0.986, \mathrm{p}=0.057\right)$, West Pokot $\left(r^{2}=-1.000, \mathrm{p}=0.006\right)$, Trans Nzoia $\left(r^{2}=\right.$ $-0.994, \mathrm{p}=0.067)$, Baringo $\left(r^{2}=-1.000, \mathrm{p}=0.007\right)$ and Nyando $\left(r^{2}=-0.992, \mathrm{p}=0.079\right)$. The Nyeri and Kiambu districts are located in the Central Province; Kakamega is in the Western. Meru North is one of the districts in the East Province; West Pokot, Trans Nzoia and Baringo are all in the Rift Valley; and Nyando is in Nyanza Province.
} 
people who went to the polls to vote "No," suggesting that at least some voting decisions had an expressive component, perhaps motivated by objections to a document that failed to fulfill President Kibaki's campaign promise. Alternatively, Kenyans voting "No" on the proposed constitutions may have done so because they expected its defeat to raise the probability of another constitution being drafted that would impose more constraints on presidential power. Such an interpretation is a matter of pure speculation, however, and one on which post-independence Kenyan history casts some doubt.

\section{Empirical Model and Results}

Our empirical model is designed to explain voting behavior in Kenya's November 2005 constitutional referendum. The basic unit of observation is the voting constituency which, as noted at the outset, number 210. In addition to measures of local economic conditions and of the extent to which constituencies have gained access to socially provided goods, we expect voting to have been influenced by partisan attributes of a constituency's political representatives which potentially are associated with the extent to which voters gain or lose from power concentration. The recent literature shows that ethnic diversity is an important determinant of economic development outcomes (Alesina et al. 1999; Easterly and Levine 1997; Collier 2000b). Ethnic diversity matters because tension between groups lowers the capacity to leverage institutional change, especially so when political power is concentrated and society is fragmented along racial, linguistic or religious lines. In other words, ethnic diversity increases the costs of cooperation against a ruling coalition. We therefore expect the members of Kenya's different ethnic groups to oppose or support constitutional change depending on the perceived benefits and costs to their group. 


\subsection{Estimation Strategy}

We specify a regression model of the determinants of voting in the constitutional referendum as follows:

$$
\begin{aligned}
\operatorname{Ln}\left(\frac{P V Y}{1-P V Y}\right) & =\alpha_{0}+\beta_{1} \text { ECONOMY }+\beta_{2} \text { SOCIAL PROVISION }+\beta_{3} \text { REPRESENTATIVE } \\
& +\beta_{4} \operatorname{Ln}\left(\frac{\text { KIBAKI }}{1-K I B A K I}\right)+\beta_{5} \text { REGION }+\beta_{6} \text { ETHNICITY }+\mu
\end{aligned}
$$

where

PVY

ECONOMY

Poverty

Unemployment

SOCLAL PROVISION

Piped Water

Secondary School

REPRESENATIVE

Cabinet

Opposition

KIB $A K I$

REGION

ETHNICITY

Ethnic Group

Ethnic Share
= Percentage voting "YES" (Constituency, 2005);

$$
\text { = Poverty rate (District, 1997); }
$$

= Rate of unemployment (District, 2000);

= Percentage of households with piped water (District, 2000);

$=$ Gross enrollment rate in secondary schools (District, 2003);

$=$ Representative is Minister or Assistant Minister (Constituency, 2005);

$=$ Representative is a member of an opposition party (Constituency, 2005);

$=$ Percentage of votes cast for Mwai Kibaki in the 2002 general election (Constituency, 2002);

= Main administrative divisions (Provinces, 2005);

= Dominant ethnic group (Constituency, 2005);

$=$ National population share of a constituency's dominant ethnic group (Constituency 2005); and 
Although our primary interest is in explaining the results of Kenya's constitutional referendum, the determinants of individuals' decisions to go to the polls at all likewise must be taken into account. Voting is a two-step process, after all: Ballots were marked in November 2005 only by those Kenyans who judged the benefits of voting for or against the proposed constitution to be greater than the costs. We therefore also specify a model of voter turnout and, since the errors from that model are in fact correlated with the errors from estimating the log-odds of voting "Yes", we estimate the two equations jointly, treating them as seemingly unrelated regressions. We report the results of a representative turnout model in the Appendix. ${ }^{8}$

As stated previously, the draft constitution was rejected by majority of Kenya's voters primarily because it did not auger genuine change as far as concentration of power in the executive branch of government was concerned. Voting "No" in the referendum can therefore be interpreted as a vote for change while "Yes" means being resistant to change and preferring the status quo. Our dependent variable is defined as the log-odds of a constituency voting to ratify the new constitution.

Economic wellbeing is proxied by poverty and unemployment rates. If we take it that economic status in a constituency reflects the cumulative effects of past policies, then higher poverty and unemployment rates would associate with lower probabilities of approving the proposed constitution if voters did not think it offered the prospect of substantial improvement in their economic circumstances. Likewise, the quality of public goods provision, as captured by the proportion of households with piped water and gross secondary school enrollment rates, should associate with higher probabilities of approving the new constitution if voters thought that its adoption would not erode their already comparatively advantageous positions. On the other hand,

\footnotetext{
${ }^{8}$ Our estimation strategy thus follows one suggested by Deacon and Shapiro (1975). However, because we define our dependent variable as the log-odds of voting "Yes", rather than adopting their logit specification, we cannot, as Deacon and Shapiro do, easily recover parameters from voters' utility functions.
} 
where social provision is poor, we expect voters to have been more likely to oppose the adoption of a constitution that did not differ radically from the existing one.

Constituencies represented by members of the cabinet are expected to have supported the proposed constitution, while those whose representatives were affiliated with parties in opposition to President Kibaki's coalition government were more likely to vote against it. Being represented by a cabinet member increases the probability of constituents benefiting from the concentration of power in the executive branch; constituencies represented by members of the opposition parties are likely to benefit less. The log-odds of voting for President Kibaki in the 2002 general election is included to capture the value assigned by his supporters and opponents to the constitutional referendum's outcome. Were Kibaki's partisans more likely to support the constitution drafted by his government because they benefited from having political power concentrated in his hands? Or were they more likely to vote "No" in retaliation for his broken presidential campaign promise? REGION and ETHNICITY control for geographic and ethnic fixed effects.

\subsection{Data}

The preferred unit of analysis is the constituency (210 observations) for which we have good data on voter choice ("Yes" or "No"), electoral support for President Kibaki in 2002, the identities of dominant ethnic groups and the characteristics of constituencies' political representatives (whether holding a cabinet post or member of an opposition party). However, the most reliable data for measuring local economic conditions (unemployment and poverty rates) and the level of public goods provision (households with piped water and gross secondary school enrollment rates) are available only at the district level (70 observations). We therefore construct district averages for these variables. Although this introduces some noise, constituencies within the same district are fairly similar and we do not expect serious biases. It is also true that observations on these variables 
are not available for 2005, when voting in the referendum took place, but are available only for various years between 1997 and 2003.

The choice of explanatory variables is largely influenced by data availability and also their perceived importance to voters. During the preparation of governmental planning documents, such as the Poverty Reduction Strategy Paper (2000) and the Economic Recovery Strategy for Wealth and Employment Creation (2003), consultations were held across Kenya to gather information about citizens' economic development priorities. As can be expected, these priorities varied regionally. Nevertheless, education (primary and secondary) and infrastructure (roads and water) were at or near the top of the list nationwide.

Enrollments in primary schools represent a potentially good constituency-level measure of public goods provision. However, a policy of free (and largely compulsory) primary education was introduced in 2003, thereby muting the variation in enrollment rates across constituencies and reducing its usefulness as a measure of cross-sectional differences in educational access. Data on roads are rather poor and although information on road density is available, it is not possible to gauge differences in quality. The proportion of households with piped water is easier to measure and also captures variations in the supply of what may be referred to as a "patronage" good whose benefits accrue only to a limited number of groups as opposed to other public goods which are more broadly available (Alesina et al. 1999). As will be shown later, piped water is also a good indicator of the level of infrastructure provision generally.

No constituency is inhabited exclusively by a single ethnic group but most constituencies are dominated by a particular group. ETHNICITY is defined herein in two ways. First, we identify the dominant ethnic group in a constituency. Second, we define ethnic share as the national population percentage of the largest ethnic group in a particular constituency. Although there are more than 30 ethnic groups in Kenya, many are fairly small and in this study we focus only on the most prominent 
groups which include the Gikuyu (Kikuyu), Embu, Meru, Luhya, Luo, Kamba, Kalenjin, Kisii, and Mji Kenda. 'The first three of these - commonly refereed to as "GEMA" - have strong ties, exhibit similar voting patterns and for all practical purposes are considered to be one ethnic group. ${ }^{10}$ GEMA is treated as such in this paper. Mij Kenda is actually a general term for several small, closely related ethnic groups in the Coast Province. Although not entirely homogenous, the voting patterns of the groups belonging to Mji Kenda are fairly uniform. The cities of Nairobi and Mombasa are, in contrast, fairly ethnically heterogeneous and we are not able to assign particular ethnic groups to constituencies in those towns. This is also true for the North Eastern Province, which is inhabited by many small groups (most living a nomadic lifestyle) and data are not available to identify the dominant groups in these areas accurately at the constituency level; ETHNICITY is coded as "Other" in these cases."

In testing for the impact of ethnicity on constitutional choice, we assume that a group's political influence is positively correlated with its size, i.e., the larger the group, the greater is its potential for monopolizing power. Although no single ethnic group controls a majority of the votes, larger groups have a comparative advantage in forging political coalitions. Put simply, larger ethnic groups are more likely to monopolize power and we therefore expect relative size to influence constitutional choice. That choice would in turn depend on a group's success in capturing power under the status quo.

Information is available on the population shares of the various ethnic groups nationally as follows: GEMA (28\%), Luhya (14\%), Luo (13\%), Kalenjin (12\%), Kamba (11\%), Kisii (6\%), Mji

\footnotetext{
${ }_{9}$ Based on data reported recently by Alesina et al. (2003, p. 186), Kenya exhibits the third-highest degree of ethnic fragmentation in the world. As of 2001, its index of ethnic fractionalization stood at 0.8588; only Liberia (0.9084) and Uganda (0.9302) rank higher.

${ }^{10}$ GEMA is an acronym for the now defunct Gikuyu-Embu-Meru Association, a voluntary tribal association that had extensive business interests and substantial political influence especially during President Kenyatta's era.

11 In fact, many ethnic groups are not perfectly homogenous. They are instead conglomerations of many clans that consider themselves distinctive. The group we refer to as Luhya, for example, is quite fragmented and its different subgroups often exhibit divergent voting patterns.
} 
Kenda $(5 \%)$ and other (1\%). For each of the constituencies, we establish the dominant ethnic group and assign ethnic shares accordingly. Thus, if GEMA is the dominant ethnic group in constituency C-1, we assign this constituency an ethnic share of 0.28 . If, on the other hand, the Luo dominate in constituency $\mathrm{C}-2$, then we assign an ethnic share of 0.13 to $\mathrm{C}-2$. Note that ethnic shares are based on total national population and not on an ethnic group's share of the population in a particular constituency. ETHNIC SHARE is generated by interacting indicator variables denoting each of Kenya's principal ethnic groups with the relevant group's national population share. The underlying assumption is that the voters in each of the constituencies know the relative size of their own group nationally and thus know the probability of capturing power. Given that it continued to centralize power in the executive branch of the Kenyan government, the larger a group's ethnic share, the higher is its probability of supporting the proposed constitution since the benefits of capturing political power are greater (and the costs of doing so are lower) when it is concentrated than when it is diffuse.

Voting data (General Election 2002 and Referendum 2005) are as officially reported by the Electoral Commission of Kenya (ECK), published in local newspapers (Daily Nation and The East African Standard). ${ }^{12}$ All other data are taken from reports produced by the Government of Kenya's Central Bureau of Statistics, including the Welfare Monitoring Survey, the Multiple Indicator Cluster Survey and the Economic Survey. Table 3 reports descriptive statistics for the variables used in the estimation.

\subsection{Results and Analysis}

Tables 4 and 5 report the results of estimating various specifications of our general model of the determinants of the log-odds of voting in favor of the proposed constitution, estimated jointly with the turnout model described in the Appendix and treating the two as seemingly unrelated regressions. Both tables include measures of local economic conditions (the poverty rate and the

\footnotetext{
12 Daily Nation: www.nationmedia.com; East Africa Standard: www.eastandard.net.
} 
unemployment rate), indicators of public goods provision (share of households with piped water and secondary school enrollment rates) and our other controls, such as representative characteristics (whether a constituency's representative is a member of the cabinet or belongs to an opposition party), the log-odds of supporting President Kibaki in the 2002 general election, which captures how strongly voters felt about his promise to devolve power, and also regional fixed effects. Table 5 also controls for ethnic groups. For the estimations presented there, the Central Province is the excluded region and GEMA is the excluded ethnic group. Voters in the Central Province and those belonging to the GEMA group overwhelmingly supported the new constitution.

The results are largely consistent in most of the specifications shown in Table 4. Both measures of the state of the local economy - unemployment and poverty rates - are associated with smaller odds of supporting the proposed constitution. The results suggest that voters are concerned about their current economic status when voting on constitutional change. The fact that voters living in areas that are more economically depressed, as evidenced by high poverty and unemployment rates, exhibit greater opposition to the new constitution suggests that they did not see much prospect for relief in it. In other words, if voters attribute their economic distress to weaknesses in a constitution, they will reject proposed changes if they do not entail significant reforms. However, poverty and unemployment rates generally are not statistically significant when ethnicity is controlled for (Table 5). This latter result likely follows from the fact that economic conditions vary systematically by ethnic groups as a result of their spatial concentration. Forty-seven percent of Kenyans live above the poverty line, on the average, but the figure is $65 \%$ in the Central Province, the ancestral homeland of the Kikuyus. In the Rift Valley, by contrast, where the Kalenjin are the dominant ethnic group, 56\% of the population lives below the poverty line (Childress 2008).

We enter the proportion of households with piped water and gross secondary school enrollments as measures of public goods provision. As noted previously, access to both water and 
education is highly valued throughout the country and voters are likely to make decisions about supporting or opposing the proposed constitution depending on how well they have been served under the existing one. Although secondary school enrollments do capture some differences across districts, education provision in Kenya is such that sizeable numbers of students study outside their home districts and thus enrollments are not a good indicator of public goods provision to specific groups and regions. Even so, the variation in enrollments could be influenced by a particular region's ability to pay.

We consider piped water to be the most salient proxy for the level of public goods provision. First, its benefits are concentrated in particular communities; hence, piped water is a good indicator of the benefits of patronage that flow from the concentration of political power. Second, simple data analysis reveals that the percentage of households with piped water is highly correlated with the presence of other infrastructure, such as electricity and telephone density: areas that have piped water are also likely to have access to additional socially provided goods. ${ }^{13}$ The different levels of social provision across the country can be attributed primarily to governmental discrimination in the allocation of public resources, which is possible owing to the concentration of political power in the executive branch. Hence, voters in regions that have been shortchanged by past governments in terms of social provision would only support a new constitution if it promises to curtail the powers of the presidency substantially.

With the exception of secondary school enrollment rates in model 5, the signs on the coefficients for these variables are as hypothesized. The proportion of households with piped water is positive and significant in all specifications. Given the high correlation between this variable and other types of infrastructure, the results imply that access to public goods is an important

\footnotetext{
${ }^{13}$ It is of course possible that high income regions are well served with infrastructure because of effective demand (people still have to pay for services). It is nevertheless true that the services are provided by the government and, hence, their allocation is politically determined.
} 
determinant of constitutional choice. While, access to piped water loses explanatory power when ethnicity is taken into account, the overall results point to the conclusion that voters who have benefited from the concentration of political power were significantly more likely to support a constitution that preserved the status quo.

Being represented by a member of President Kibaki's cabinet raised the odds of voting for the proposed constitution, although not significantly so in most specifications. Being represented by a member of an opposition party as a rule reduced the likelihood of such support. Again, however, the estimated coefficients are not statistically different from zero as a rule. The interpretation here is that partisanship does not matter very much. The empirical results by and large fail to support our conjectures that constituencies having a strong voice in the executive branch had good reason to favor continuing the concentration of political power in the office of the president, while those which had sent members of an opposition party to Nairobi would not.

Other things being the same, voters who backed President Kibaki in 2002 were more likely to cast their ballots against ratifying the new constitution he proposed in 2005 . It appears that the breaking of his campaign promise provoked a major backlash against him personally. This finding suggests that many of those who supported Kibaki in 2002 did so in the expectation that, as president, he would cede power to the legislative branch of government. On the other hand, those who supported the ratification of the draft constitution expected to continue to benefit from Kibaki's continued exercise of strong executive power. Given that the new constitution was defeated soundly, defections from the coalition that elected him to office in 2002 are equally evident. The perceived welfare loss to opponents from the adoption of the constitution apparently was much greater than the expected welfare gain by its proponents.

The regional variables indicate that, compared to the Central Province, voters elsewhere generally were less supportive of the new constitution. This holds true even when ethnicity is 
controlled for. Likewise, when the regional controls are omitted, the results show that other ethnic groups were more opposed to the proposed constitution than the GEMA group, which overwhelmingly voted "Yes." However, when regional controls are included, only the Kalenjin and Kamba were significantly more likely to vote "No" (Table 5).

The reason that the votes of some ethnic groups - specifically, the Lubya, the Luo and "other" - no longer differ significantly from the GEMA when we control for region is that ethnicity is closely tied to geography in Kenya. ${ }^{14}$ Indeed, taking spatial concentration into account helps explain why the estimated coefficient on Kisii switches sign in Table 5's last column. The Kisii share ground with the Luos in Nyanza Province, which overall was less likely to vote to ratify the new constitution than was the omitted Central Province. Only $1.4 \%$ of the latter group voted for the proposed constitution, compared with $42 \%$ of the former (see Table 1). Including regional fixed effects isolates the Kisii's comparatively greater level of support. In any case, these results indicate the combined importance of regionalism and ethnicity in constitutional decisions.

The results concerning the importance of ethnicity in constitutional choice requires some further analysis in order to shed light on why particular ethnic groups vote the way they do. Capturing political power in weak states can be expected to benefit some ethnic groups at the expense of others. It is therefore reasonable to assume that all ethnic groups would like to monopolize power, giving rulers incentive to broker wealth transfers among them. ${ }^{15}$ We can hypothesize that the greater is an ethnic group's potential for capturing power, the more likely it is that the members of that group would support a constitution that endows the executive with substantial powers.

\footnotetext{
14 The same reasoning explains why the last column of Table 5 does not include coefficient estimates for the Northeastern Province or for the Mij Kenda. We are unable to identify a dominant group for the Northeastern Province owing to the ethnic heterogeneity of that region. Similarly, the Mij Kenda are omitted from this specification because they are concentrated in the Coast Province.

15 This is consistent with the ethnic rent-seeking literature as advanced by, for example, Kimenyi and Mbaku (1993) and Kimenyi (1998).
} 
Table 6 reports the results of various specifications of the general model in which we include the square of the national population share of each constituency's dominant ethnic group. ${ }^{16}$ The variable is positive and significant, suggesting that the demand for power concentration increases with the square of group size. Smaller groups, with low probabilities of successfully monopolizing power, seem to have a greater demand for power diffusion.

One question we are unable to address at present is the extent to which a major Kenyan land reform initiative may have influenced voting on the constitutional referendum. A policy formulated by the land ministry in Nairobi proposed to repossess all Coast Province land owned by "absentee landlords", mostly British, Arab and Kenyan politicians, and transfer title to it to squatters. Although President Kibaki did not begin actually seizing land by presidential decree until $2006,{ }^{17}$ it is possible that the land reform issue determined at least some voters' positions on the proposed constitution. It is perhaps noteworthy in that regard that our results suggest that Kenyans living in the Coast Province were significantly more likely to vote "No" in November 2005.

\section{Conclusion}

This paper analyzes voting in Kenya's 2005 constitutional referendum. The proposed constitution was rejected overwhelmingly by the voters because it failed substantially to curtail the powers of the nation's chief executive. The paper reports some empirical models of the demand for power diffusion. The study is unique in that it is the first of which we are aware to estimate empirically the determinants of constitutional choice in a developing country setting using the rational choice framework. The shortcomings of the data notwithstanding, the estimation results are quite robust to changes in model specification and provide strong support for recent theoretical advances in the economic development literature, spearheaded by Acemoglu and others, concerning resistance to

16 The ethnic group population shares are entered as whole numbers; squaring gives greater weight to larger groups.

${ }_{17}$ BBC News, http://news.bbc.co.uk/2/low/africa/5275670.stm, August 22, 2006. 
institutional change and its implications for growth. Finally, this study identifies a channel through which ethnicity can hinder growth. Our results suggest that ethnic heterogeneity can impede development by slowing the power diffusion process.

The ethnic divisions evident in the voting on President Kibaki's proposed constitution turned violent in December 2007, after he was declared to have defeated Raila Odinga in an election that his supporting coalition, comprised primarily of Luos, Luhyas and Kalenjins, charged was marked by widespread vote fraud. More than 800 Kenyans are reported to have been killed and as many as 250,000 to have been displaced in the post-election attacks launched by Luos and Kalenjins against Kikuyu homes and businesses, primarily in the Rift Valley town of Eldoret (Childress 2008). It remains to be seen whether a power-sharing arrangement between Kibaki and Odinga, brokered by former U.N. Secretary Kofi Anan in February 2008, will hold.

The results of the 2005 Kenyan constitutional referendum and 2007-2008's bloodshed point to the importance of designing institutions that harmonize ethnic claims in divided societies. Concentration of political power in such societies is often used to marginalize some groups and to provide patronage goods to others. An appropriate institutional change would be one that lowers the benefits of power concentration through constitutional decentralization.

\section{Appendix}

All results of voting in November 2005 reported in the text are obtained by jointly estimating seemingly unrelated regressions for the determinants of the log-odds of voting in favor of President Kibaki's proposed constitution and the determinants of voting at all (turnout). We specify the voter turnout model as follows:

$$
\operatorname{Ln}\left(\frac{P V}{1-P V}\right)=f(\text { ECONOMY, POPDEN, ARE } A, C L O S E, \text { REGION })
$$


where

$$
\begin{aligned}
\text { PV }= & \begin{array}{l}
\text { percentage of a constituency's registered voters who voted in the } \\
\text { referendum (voter turnout); }
\end{array} \\
\text { POPDEN } & \text { constituency population density; } \\
\text { AREA } A \text { geographic size of the constituency in square miles; } & \\
\text { CLOSENESS = } & \text { closeness in the referendum voting expressed as the absolute difference } \\
& \text { between "Yes" and "No" votes; and }
\end{aligned}
$$

ECONOMY and REGION are as defined previously. Although the coefficients and standard errors of the turnout model vary across their jointly estimated companion specifications in Tables $4-6$, we report a set of representative SUR results in Table A1. (We would be happy to supply the other estimates of the turnout model upon request.)

The results of estimating the determinants of log-odds of voting either "Yes" or "No" are largely consistent with a priori expectations. According to the literature on voter participation (see Geys 2006 for a recent survey), greater POVERTY and higher UNEMPLOYMENT are expected to have a negative impact on voter turnout, and that is what we find. The log-odds of voting likewise is expected to be lower in areas that are densely populated and geographically large. Voter free-riding becomes more likely as population density increases and this tends to suppress turnout. Lower voter turnout rates in urban areas could also be due to city dwellers' higher opportunity costs of time. In Kenya, there is clear evidence of lower turnout in urban areas as compared to rural areas and the results in Table A1 offer support for that conjecture.

$L A N D A R E A$ is negatively related to turnout. Constituencies that are geographically large raise the costs of voting because people have to travel long distances to polling places and also because of poor roads and communication networks in most of Kenya's sparsely populated areas. Because one person's vote is less likely to be decisive, voter turnout is expected to be lower in constituencies where the raw vote margin between "Yes" and "No" votes is larger. However, the 
estimated coefficient on CLOSENESS is positive and significant, suggesting that, other things being the same, voter turnout rates were higher in constituencies where the constitutional referendum's margin of victory or defeat was wider. This unexpected finding could be due to the important role played by ethnicity in explaining support or opposition to the new constitution. Indeed, the results suggest that, compared to the Central Province, turnout rates were significantly higher in the Rift Valley, a center of Kalenjin opposition to the Kikuyu-dominated Kibaki administration, but that they were significantly lower in the Coast and Western provinces, both of which also were more likely to vote "No" in November 2005. 
Table A1. SUR Results (Dependent Variable= Log-odds of Voting in the Referendum)

\begin{tabular}{|c|c|}
\hline Explanatory variable & Model 1 \\
\hline Intercept & $\begin{array}{l}1.000^{* * *} \\
(5.23)\end{array}$ \\
\hline Poverty & $\begin{array}{l}-0.009 * * \\
(-2.41)\end{array}$ \\
\hline Unemployment & $\begin{array}{l}-0.047 * * * \\
(-4.84)\end{array}$ \\
\hline Population Density & $\begin{array}{l}-0.000^{* *} \\
(-2.26)\end{array}$ \\
\hline Area & $\begin{array}{l}-0.000 * * * \\
(-4.67)\end{array}$ \\
\hline Closeness & $\begin{array}{l}0.008^{* * *} \\
(7.74)\end{array}$ \\
\hline Northeastern Province & $\begin{array}{l}-0.231 \\
(-0.94)\end{array}$ \\
\hline East Province & $\begin{array}{l}0.041 \\
(0.24)\end{array}$ \\
\hline Coast Province & $\begin{array}{l}-0.469 * * \\
(-2.78)\end{array}$ \\
\hline Nyanza Province & $\begin{array}{l}-0.152 \\
(-0.99)\end{array}$ \\
\hline Western Province & $\begin{array}{l}-0.430 * * \\
(-2.56)\end{array}$ \\
\hline Rift Valley Province & $\begin{array}{l}0.506^{* * *} \\
(3.80)\end{array}$ \\
\hline Nairobi Province & $\begin{array}{l}0.134 \\
(0.42)\end{array}$ \\
\hline
\end{tabular}

Notes: See Table 4 . The system adjusted- $\mathrm{R}^{2} \mathrm{~s}$ are reported in the main text in the corresponding models of the determinants of the log-odds of voting "Yes". 


\section{References}

Acemoglu, Daron, Johnson, Simon \& Robinson, James A. (2001). "The Colonial Origins of Comparative Development: An Empirical Investigation," American Economic Review 91(5): 1369-1401.

Acemoglu, Daron, Johnson, Simon \& Robinson, James A. (2005). "The Rise of Europe: Atlantic Trade, Institutional Change, and Economic Growth," American Economic Review, 95(3): 546579.

Acemoglu, Daron \& Robinson, James A. (2000a). "Political Losers as a Barrier to Economic Development," American Economic Review 90(2): 126-130.

Acemoglu, Daron \& Robinson, James A. (2000b). "Why Did the West Extend the Franchise? Democracy, Inequality and Growth in Historical Perspective," Quarterly Journal of Economics 115(4): 1167-1200.

Alesina, Alberto, Baqir, Reza \& Easterly, William (1999). "Public Goods and Ethnic Divisions," Quarterly Journal of Economics 114(4): 1243-1284.

Alesina, Alberto, Devleeschauwer, Arnaud, Easterly, William, Kurlat, Sergio \& Wacziarg, Romain (2003). "Fractionalization," Journal of Economic Growth 8(2): 155-194.

Basuchoudhary, Atin \& Shughart, William F. II (2006). "On Ethnic Conflict and the Origins of Terrorism,” Working Paper, Virginia Military Institute, Lexington, VA.

Beard, Charles A. ([1913] 1986). An Economic Interpretation of the Constitution of the United States. New York: Free Press.

Buchanan, James M. (1980). "Rent Seeking and Profit Seeking." In Buchanan, James M., Tollison, Robert D. \& Tullock, Gordon (eds.), Toward a Theory of the Rent Seeking Society, 3-15. College Station: Texas A\&M University Press.

Buchanan, James M. \& Tullock, Gordon (1962). The Calculus of Consent: Logical Foundations of Constitutional Democracy. Ann Arbor: University of Michigan Press.

Butler, David \& Ranney, Austin (eds.) (1994). Referendums around the World: The Growing Use of Direct Democracy. Washington, DC: AEI Press.

Childress, Sarah (2008). "Violence in Kenya Exposes Tribes' Widening Wealth Gap." Wall Street Journal (January 30): A1 \& A18.

Collier, Paul (2000a). "Economic Causes of Civil Conflict and their Implications for Policy." World Bank: The Economics of Civil War, Crime and Violence Project. http://www.worldbank.org /research/conflict/papers/civilconflict.pdf; accessed 9 November 2006.

Collier, Paul (2000b). "Ethnicity, Politics and Economic Performance," Economics and Politics 12(3): 1225-1245. 
Clarke, Harold D. \& Kornberg, Allan (1994). "The Politics and Economics of Constitutional Choice: Voting in Canada's 1992 National Referendum," Journal of Politics 56(4): 940-962.

Coate, Stephen \& Conlin, Michael (2004). "A Group Rule-Utilitarian Approach to Voter Turnout: Theory and Evidence," American Economic Review 94(5): 1476-1504.

Dawkins, Richard (1974). The Selfish Gene. Oxford: Oxford University Press.

Deacon, Robert T. \& Shapiro, Perry (1975). "Private Preference for Collective Goods Revealed through Voting on Referenda," American Economic Review 65(5): 943-955.

Easterly, William (2000). “Can Institutions Resolve Conflict?” Policy Research Working Paper 2482. World Bank Development Research Group, Washington, DC.

Easterly, William \& Levine, Ross (1997). “Africa's Growth Tragedy: Policies and Ethnic Divisions," Quarterly Journal of Economics 112(4): 1203-1250.

Electoral Commission of Kenya (2002). 2002 General Election Results. Nairobi: Electoral Commission of Kenya.

Electoral Commission of Kenya (2005). 2005 Constitutional Referendum Results. Nairobi: Electoral Commission of Kenya.

Fidrmuc, Jan (2000). "Political Support for Reforms: Economics of Voting in Transition Countries," European Economic Review 44(8): 1491-1513.

Geys, Benny (2006). "Explaining Voter Turnout: A Review of Aggregate-Level Research,” Electoral Studies 25: 637-663.

Gifford, Adam (2004). "Group Roles in Evolution and Cognition." In Rowley, Charles K. \& Schneider, Friedrich (eds.), The Encyclopedia of Public Choice, vol. II, 264-268. Dordrecht: Kluwer Academic Publishers.

Glaeser, Edward L. (2005). "The Political Economy of Hatred." Quarterly Journal of Economics 120(1): $45-86$.

Government of Kenya, Central Bureau of Statistics (2002a). Kenya Multiple Indicator Cluster Survey 2000. Nairobi, Kenya.

Government of Kenya, Central Bureau of Statistics (2002b). Welfare Monitoring Survey 1997. Nairobi, Kenya.

Government of Kenya, Central Bureau of Statistics (2004). The Economic Survey 2004. Nairobi, Kenya.

Hardin, Russell (1995). One for All: The Logic of Group Conflict. Princeton, NJ: Princeton University Press. 
Kimenyi, Mwangi S. (1998). "Ethnic Rent-Seeking, Stability and Institutional Reforms in SubSaharan Africa." In Borner, Silvio \& Paldam, Martin (eds.), The Political Dimension of Economic Growth, 324-335. New York: St. Martin Press.

Kimenyi, Mwangi S. (2006). "Political Constipation: Both Bananas and Oranges are Bad for Kenya's Institutional Health," University of Connecticut Working Paper.

Kimenyi, Mwangi S. \& Mbaku, John M. (1993). "Rent-Seeking and Institutional Stability in Developing Countries,” Public Choice 77(2): 385-405.

Kimenyi, Mwangi S. \& Shughart, William F. II (1989). "Political Successions and the Growth of Government." Public Choice 62(2): 173-179.

Kirk, Richard (1983). "Political Terrorism and the Size of Government: A Positive Institutional Analysis of Violent Political Activity." Public Choice 40(1): 41-52.

Landa, Janet T. (1994). Trust, Ethnicity, and Identity: Beyond the New Institutional Economics of Trading Networks. Ann Arbor: University of Michigan Press.

Landes, William M. \& Posner, Richard A. (1975). "The Independent Judiciary in an Interest-Group Perspective." Journal of Law and Economics 18(3): 875-901.

Matsusaka, John (1992). "Economics of Direct Legislation," Quarterly Journal of Economics 107(2): 541-571.

Matsusaka, John (2005). "The Eclipse of Legislatures: Direct Democracy in the 21st Century," Public Choice 124 (1-2): 157-177.

McGuire, Robert A. (1988). "Constitution Making: A Rational Choice Model of the Federal Convention of 1787.” Journal of Political Science 32(2): 483-522.

McGuire, Robert A. (2003). To Form a More Perfect Union: A New Economic Interpretation of the United States Constitution. Oxford and New York: Oxford University Press.

McGuire, Robert A. \& Ohsfeldt, R. (1986). "An Economic Model of Voting Behavior over Specific Issues at the Constitutional Convention of 1787." Journal of Economic History 46(1): 79-111.

McGuire, Robert A. \& Ohsfeldt, R. (1989). "Self-Interest, Agency Theory, and Political Voting Behavior: The Ratification of the United States Constitution." American Economic Review 79(1): 219-234.

McGuire, Robert A. \& Ohsfeldt, R. (1997). "Constitutional Economics and the American Founding." Research in Law and Economics 18: 143-171.

Mueller, Dennis C. (1997). “Constitutional Public Choice.” In Mueller, Dennis C. (ed.), Perspectives on Public Choice: A Handbook, 124-146. Cambridge: Cambridge University Press.

North, Douglass C. (1981). Structure and Change in Economic History. New York: Norton. 
North, Douglass C. \& Thomas, R. P. (1973). The Rise of the Western World: A New Economic History. Cambridge: Cambridge University Press.

North, Douglass C. \& Weingast, Barry R. (1989). "Constitutions and Commitment: The Evolution of Institutions Governing Public Choice in Seventeen-Century England," Journal of Economic History 49(4): 803-832.

Olson, Mancur (1965). The Logic of Collective Action: Public Goods and the Theory of Groups. Cambridge: Harvard University Press.

Olson, Mancur (1982). The Rise and Decline of Nations: Economic Growth, Stagflation, and Economic Rigidities. New Haven: Yale University Press.

Olson, Mancur (1993). "Dictatorship, Democracy and Development," American Political Science Review 87(3): 567-576.

Olson, Mancur (1997). “The New Institutional Economics: The Collective Choice Approach to Economic Development." In Clague, Christopher (ed.), Institutions and Economic Development: Growth and Government in Less-Developed and Post-Socialist Countries, 37-64. Baltimore: John Hopkins University Press.

Odhiambo, Walter (2004). Pulling Apart: Facts and Figures on Inequality in Kenya. Nairobi, Kenya: Society for International Development.

Powellson, John P. (1994). Centuries of Economic Endeavor, Ann Arbor: University of Michigan Press.

Remmer, Karen L. \& Gelineau, Francois (2003). "Subnational Electoral Choice: Economic and Referendum Voting in Argentina, 1983-1999," Comparative Political Studies 36(7): 801-821.

Sen, Amartya (2006). Identity and Violence. New York: Norton.

Vlachos, Jonas (2005). "Who Wants Political Integration? Evidence from the Swedish EUMembership Referendum,” Journal of Public Economics 88(7-8): 1589-1604. 
Figure 1. Kenya's Political Boundaries

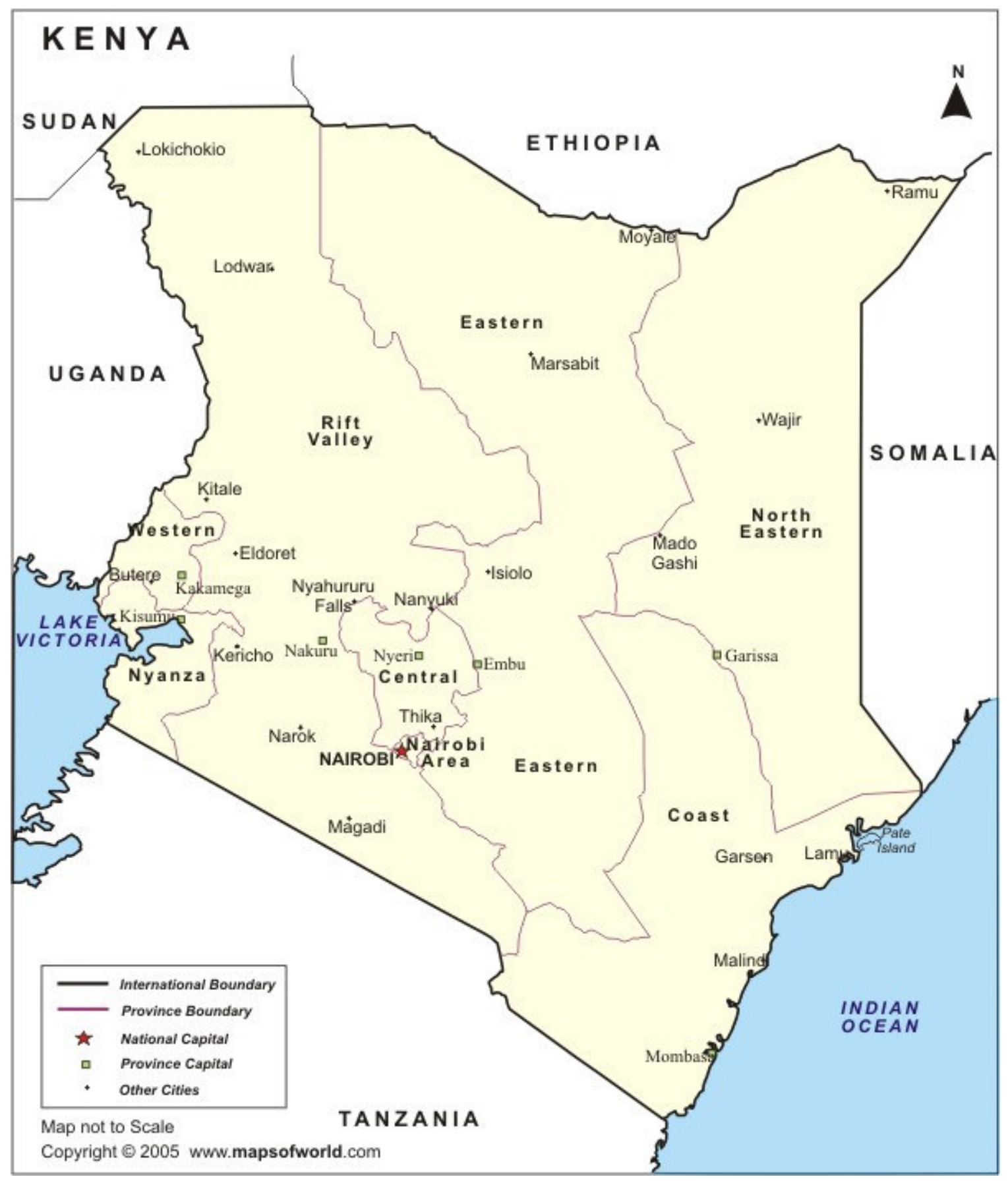


Table 1. Constitutional Referendum Results, November 2005

\begin{tabular}{|c|c|c|c|c|}
\hline Unit & $\begin{array}{c}\text { Number of } \\
\text { constituencies }\end{array}$ & $\begin{array}{c}\text { Percent voting } \\
\text { YES }\end{array}$ & $\begin{array}{c}\text { Referendum } \\
\text { voter turnout }\end{array}$ & $\begin{array}{l}\text { Percent voting for } \\
\text { President Kibaki } \\
\text { in } 2002 \\
\end{array}$ \\
\hline NATIONAL & 210 & 38.0 & 59.34 & 57.65 \\
\hline PROVINCES & & & & \\
\hline 1. Nairobi & 8 & 43.35 & 42.33 & 73.54 \\
\hline 2. Coast & 21 & 20.65 & 41.00 & 56.49 \\
\hline 3. Northeast & 11 & 25.43 & 27.26 & 28.05 \\
\hline 4. Eastern & 36 & 47.33 & 60.20 & 65.28 \\
\hline 5. Central & 29 & 93.28 & 72.18 & 69.24 \\
\hline 6. Rift Valley & 49 & 22.92 & 71.86 & 39.09 \\
\hline 7. Western & 24 & 37.81 & 50.36 & 73.33 \\
\hline 8. Nyanza & 32 & 15.04 & 61.57 & 62.20 \\
\hline DISTRICTS & & & & \\
\hline 1. Nairobi & 8 & 43.35 & 42.33 & 73.54 \\
\hline 2. Mombassa & 4 & 20.85 & 29.92 & 75.07 \\
\hline 3. Kwale & 3 & 12.41 & 43.42 & 55.35 \\
\hline 4. Kilifi & 3 & 14.59 & 37.52 & 71.51 \\
\hline 5. Malindi & 2 & 11.56 & 37.60 & 63.88 \\
\hline 6. Tana River & 3 & 15.43 & 44.25 & 31.04 \\
\hline 7. Lamu & 2 & 34.67 & 49.13 & 30.90 \\
\hline 8. Taita & 4 & 32.62 & 48.09 & 55.69 \\
\hline 9. Garissa & 4 & 12.68 & 27.16 & 20.36 \\
\hline 10. Wajir & 4 & 28.00 & 24.71 & 31.79 \\
\hline 11. Mandera & 3 & 39.00 & 30.81 & 33.32 \\
\hline 12. Moyale & 1 & 47.36 & 42.14 & 24.61 \\
\hline 13. Marasbit & 3 & 26.21 & 46.60 & 30.34 \\
\hline 14. Isiolo & 2 & 40.95 & 48.32 & 28.24 \\
\hline 15. Meru North & 4 & 84.06 & 80.71 & 60.13 \\
\hline 16. Meru Central & 3 & 95.70 & 68.08 & 74.59 \\
\hline 17. Meru South & 1 & 94.93 & 66.41 & 67.50 \\
\hline 18. Tharaka & 1 & 86.21 & 69.39 & 61.88 \\
\hline 19. Embu & 2 & 94.59 & 64.58 & 79.13 \\
\hline 20. Mbeere & 2 & 77.18 & 58.99 & 57.31 \\
\hline 21. Mwingi & 2 & 14.90 & 65.43 & 90.39 \\
\hline 22. Kitui & 4 & 28.00 & 50.36 & 76.22 \\
\hline 23. Machakos & 6 & 11.71 & 57.93 & 76.88 \\
\hline 24. Makueni & 5 & 25.16 & 59.77 & 72.90 \\
\hline 25. Nyandarua & 4 & 96.14 & 77.35 & 66.99 \\
\hline 26. Nyeri & 6 & 98.39 & 76.53 & 96.25 \\
\hline 27. Kirinyaga & 4 & 96.96 & 80.25 & 88.13 \\
\hline 28. Muranga & 3 & 96.85 & 70.22 & 78.57 \\
\hline 29. Maragwa & 3 & 97.32 & 72.80 & 71.35 \\
\hline 30. Thika & 4 & 79.86 & 61.05 & 39.79 \\
\hline 31. Kiambu & 5 & 88.12 & 66.11 & 40.24 \\
\hline 32. Turkana & 3 & 26.04 & 31.96 & 43.78 \\
\hline 33. West Pokot & 3 & 4.36 & 68.45 & 19.22 \\
\hline 34. Samburu & 2 & 9.70 & 59.55 & 36.71 \\
\hline 35. Trans Nzoia & 3 & 55.15 & 53.27 & 64.52 \\
\hline
\end{tabular}




\begin{tabular}{|c|c|c|c|c|}
\hline Unit & $\begin{array}{l}\text { Number of } \\
\text { constituencies }\end{array}$ & $\begin{array}{c}\text { Percent voting } \\
\text { YES }\end{array}$ & $\begin{array}{c}\text { Referendum } \\
\text { voter turnout }\end{array}$ & $\begin{array}{l}\text { Percent voting for } \\
\text { President Kibaki } \\
\text { in } 2002\end{array}$ \\
\hline 36. Usian Gishu & 3 & 16.33 & 74.21 & 37.38 \\
\hline 37. Marakwet & 2 & 1.69 & 99.01 & 35.82 \\
\hline 38. Keiyo & 2 & 1.73 & 87.43 & 18.43 \\
\hline 39. Nandi North & 2 & 6.44 & 78.42 & 41.30 \\
\hline 40. Nandi South & 2 & 8.45 & 76.22 & 39.94 \\
\hline 41. Baringo & 3 & 18.61 & 77.97 & 7.76 \\
\hline 42. Koibatek & 2 & 9.05 & 96.16 & 13.73 \\
\hline 43. Laikipia & 2 & 83.61 & 64.88 & 78.96 \\
\hline 44. Nakuru & 6 & 62.35 & 65.98 & 53.53 \\
\hline 45. Trans Mara & 1 & 7.00 & 73.12 & 54.73 \\
\hline 46. Narok & 2 & 6.90 & 78.33 & 45.97 \\
\hline 47. Kajiado & 3 & 29.20 & 65.25 & 61.42 \\
\hline 48. Bomet & 3 & 2.92 & 84.14 & 24.78 \\
\hline 49. Bureti & 2 & 2.92 & 83.94 & 32.54 \\
\hline 50. Kericho & 3 & 7.76 & 79.54 & 25.46 \\
\hline 51. Kakamega & 4 & 38.10 & 49.78 & 76.27 \\
\hline 52. Lugari & 1 & 13.19 & 31.13 & 89.10 \\
\hline 53. Butere Mumias & 4 & 29.60 & 47.88 & 75.89 \\
\hline 54. Vihiga & 4 & 16.88 & 45.72 & 67.69 \\
\hline 55. Mt. Elgon & 1 & 22.28 & 75.27 & 26.87 \\
\hline 56. Bungoma & 5 & 80.93 & 51.57 & 81.63 \\
\hline 57. Teso & 1 & 4.89 & 65.11 & 51.89 \\
\hline 58. Busia & 4 & 31.04 & 51.44 & 76.18 \\
\hline 59. Siaya & 3 & 1.14 & 57.09 & 90.21 \\
\hline 60. Bondo & 2 & 2.76 & 70.22 & 94.83 \\
\hline 61. Kisumu & 3 & 2.48 & 54.92 & 92.25 \\
\hline 62. Nyando & 3 & 1.32 & 66.79 & 96.77 \\
\hline 63. Rachuonyo & 2 & 0.68 & 78.50 & 95.75 \\
\hline 64. Homa Bay & 2 & 0.76 & 72.34 & 88.36 \\
\hline 65. Migori & 4 & 1.01 & 84.03 & 88.63 \\
\hline 66. Suba & 2 & 1.32 & 72.79 & 94.35 \\
\hline 67. Kuria & 1 & 31.01 & 61.84 & 16.22 \\
\hline 68. Gucha & 3 & 41.07 & 44.44 & 2.98 \\
\hline 69. Kisii & 5 & 41.26 & 43.84 & 3.96 \\
\hline 70. Nyamira & 2 & 45.49 & 47.85 & 3.80 \\
\hline ETHNIC GROUPS & & & & \\
\hline 1. Kikuyu & & 93.28 & 72.18 & 75.60 \\
\hline 2. Embu & & 83.38 & 61.83 & 84.60 \\
\hline 3. Meru & & 90.79 & 72.45 & 86.70 \\
\hline 4. Luhya & & 37.81 & 50.34 & 73.57 \\
\hline 5. Luo & & 1.43 & 69.19 & 85.37 \\
\hline 6. Kalenjin & & 16.13 & 70.78 & 29.38 \\
\hline 7. Kamba & & 19.87 & 57.57 & 77.14 \\
\hline 8. Kisii & & 42.05 & 44.82 & 3.65 \\
\hline 9. Mji Kenda & & 19.09 & 40.48 & 56.49 \\
\hline
\end{tabular}


Table 2. Correlations between Percentage Voting Yes and Voter Turnout by Region and Ethnicity

\begin{tabular}{|l|c|c|}
\hline Region or Group & Coefficient & Significance \\
\hline NATIONAL & 0.079 & 0.256 \\
PROVINCES & & 0.265 \\
Nairobi & 0.449 & 0.055 \\
Coast & 0.424 & 0.533 \\
Northeast & 0.211 & 0.038 \\
East & 0.342 & 0.000 \\
Rift Valley & -0.508 & 0.890 \\
Western & -0.030 & 0.000 \\
Nyanza & -0.758 & \\
ETHNC GROUPS & & 0.000 \\
GEMA & 0.475 & 0.908 \\
Luhya & -0.024 & 0.001 \\
Luo & -0.607 & 0.000 \\
Kalenjin & -0.631 & 0.800 \\
Kamba & 0.066 & 0.224 \\
Kisii & -0.422 & 0.055 \\
Mkenda & 0.424 & 0.373 \\
Other & -0.195 & \\
\hline
\end{tabular}


Table 3. Descriptive Statisticsa

\begin{tabular}{|l|c|c|}
\hline \multicolumn{1}{|c|}{ Variable } & Mean & Standard Deviation \\
\hline Percent voting "Yes" & 38.00 & 34.29 \\
Poverty rate & 54.98 & 13.22 \\
Unemployment rate & 9.60 & 4.73 \\
Percent with piped water & 24.59 & 23.17 \\
Secondary school enrollment & 22.02 & 14.78 \\
Member of cabinet & 0.33 & 0.69 \\
Opposition member & 0.40 & 0.49 \\
Percent voting for Kibaki in 2002 & 57.72 & 27.96 \\
Percent voting (turnout) & 59.23 & 17.91 \\
Area of the constituency & 8731.33 & 1483.28 \\
Population density & 374.48 & 683.69 \\
Closeness & 65.37 & 31.37 \\
Eastern Province & 0.176 & 0.381 \\
Coast Province & 0.100 & 0.300 \\
Nyanza Province & 0.152 & 0.360 \\
Western province & 0.114 & 0.318 \\
North Eastern Province & 0.052 & 0.223 \\
Nairobi Province & 0.038 & 0.191 \\
Central Province & 0.138 & 0.345 \\
Kikuyu-Embu-Meru & 0.21 & 0.41 \\
Luhya & 0.11 & 0.32 \\
Luo & 0.12 & 0.33 \\
Kalenjin & 0.19 & 0.39 \\
Kamba & 0.08 & 0.27 \\
Kisii & 0.05 & 0.21 \\
Mji Kenda & 0.10 & 0.30 \\
Other & 0.10 & 0.31 \\
\hline
\end{tabular}

${ }^{a}$ Note that the summary statistics shown here are based on Kenya's 210 parliamentary constituencies. Regional and ethnic statistics therefore reflect shares of constituencies per province and shares of constituencies where particular ethnic groups are dominant, respectively. Thus the ethnic means do not correspond to national population shares. 
Table 4. Determinants of Constitutional Choice

\begin{tabular}{|c|c|c|c|c|c|}
\hline Explanatory variable & Model 1 & Model 2 & Model 3 & Model 4 & Model 5 \\
\hline Intercept & $\begin{array}{l}4.286^{* * *} \\
(6.16)\end{array}$ & $\begin{array}{l}0.545 \\
(0.62)\end{array}$ & $\begin{array}{l}0.311 \\
(0.33)\end{array}$ & $\begin{array}{l}0.288 \\
(0.31)\end{array}$ & $\begin{array}{l}4.014^{* * *} \\
(4.99)\end{array}$ \\
\hline Poverty & $\begin{array}{l}-0.071 * * * \\
(-6.16)\end{array}$ & $\begin{array}{l}-0.042^{* * *} \\
(-3.57)\end{array}$ & $\begin{array}{l}-0.040^{* * *} \\
(-3.43)\end{array}$ & $\begin{array}{l}-0.037 * * * \\
(-3.13)\end{array}$ & $\begin{array}{l}-0.018 \\
(-1.42)\end{array}$ \\
\hline Unemployment & $\begin{array}{l}-0.134 * * * \\
(-4.18)\end{array}$ & $\begin{array}{l}-0.082^{* *} \\
(-2.48)\end{array}$ & $\begin{array}{l}-0.069 * * \\
(-2.07)\end{array}$ & $\begin{array}{l}-0.069^{*} \\
(-2.07)\end{array}$ & $\begin{array}{l}-0.131 \text { *** } \\
(-4.28)\end{array}$ \\
\hline Piped water & & $\begin{array}{l}0.030^{* * *} \\
(4.68)\end{array}$ & $\begin{array}{l}0.0286^{* * *} \\
(4.25)\end{array}$ & $\begin{array}{l}0.030 * * * \\
(4.47)\end{array}$ & $\begin{array}{l}0.041^{* * *} \\
(6.00)\end{array}$ \\
\hline Secondary school & & $\begin{array}{l}0.042 * * * \\
(3.92)\end{array}$ & $\begin{array}{l}0.042^{* * *} \\
(3.98)\end{array}$ & $\begin{array}{l}0.045^{* * *} \\
(4.22)\end{array}$ & $\begin{array}{l}-0.011 \\
(-1.28)\end{array}$ \\
\hline Cabinet & & & $\begin{array}{l}0.649 * \\
(1.76)\end{array}$ & $\begin{array}{l}0.686^{*} \\
(1.86)\end{array}$ & $\begin{array}{l}0.244 \\
(0.90)\end{array}$ \\
\hline Opposition & & & $\begin{array}{l}-0.112 \\
(-0.38)\end{array}$ & $\begin{array}{l}-0.597 \\
(-1.41)\end{array}$ & $\begin{array}{l}-0.959 * * * \\
(-2.97)\end{array}$ \\
\hline Kibaki & & & & $\begin{array}{l}-0.202 \\
(-1.56)\end{array}$ & $\begin{array}{l}-0.403^{* * *} \\
(-4.06)\end{array}$ \\
\hline Northeastern Province & & & & & $\begin{array}{l}-1.336 \\
(-1.61)\end{array}$ \\
\hline East Province & & & & & $\begin{array}{l}-1.246^{* *} \\
(-2.21)\end{array}$ \\
\hline Coast Province & & & & & $\begin{array}{l}-3.491 \text { *** } \\
(-5.93)\end{array}$ \\
\hline Nyanza Province & & & & & $\begin{array}{l}-4.551 \text { *** } \\
(-8.70)\end{array}$ \\
\hline Western Province & & & & & $\begin{array}{l}-2.612^{* * *} \\
(-4.78)\end{array}$ \\
\hline Rift Valley Province & & & & & $\begin{array}{l}-4.040^{* * *} \\
(-8.12)\end{array}$ \\
\hline Nairobi Province & & & & & $\begin{array}{l}-5.647^{* * *} \\
(-6.47)\end{array}$ \\
\hline Adjusted $\mathrm{R}^{2}$ & 0.609 & 0.624 & 0.626 & 0.630 & 0.718 \\
\hline
\end{tabular}

Notes: Dependent variable $=\log$ odds of voting "Yes". $\mathrm{N}=210 . t$-statistics in parentheses. Asterisks denote significance at the 1 percent $(* * *), 5$ percent $(* *)$ and 10 percent $(*)$ levels. Central Province is the omitted region. $\mathrm{R}^{2}$ is the system-weighted coefficient of multiple determination. 
Table 5: Determinants of Constitutional Choice, Including Ethnic Groups

\begin{tabular}{|c|c|c|c|c|c|}
\hline Explanatory variable & Model 1 & Model 2 & Model 3 & Model 4 & Model 5 \\
\hline Intercept & $\begin{array}{l}2.986^{* * *} \\
(6.48)\end{array}$ & $\begin{array}{l}1.357 * \\
(1.98)\end{array}$ & $\begin{array}{l}1.185^{*} \\
(1.68)\end{array}$ & $\begin{array}{l}1.199 * \\
(1.69)\end{array}$ & $\begin{array}{l}2.395^{* * *} \\
(3.78)\end{array}$ \\
\hline Poverty & $\begin{array}{l}-0.005 \\
(-0.66)\end{array}$ & $\begin{array}{c}0.003 \\
(0.39)\end{array}$ & $\begin{array}{c}0.004 \\
(0.52)\end{array}$ & $\begin{array}{c}0.004 \\
(0.46)\end{array}$ & $\begin{array}{l}-0.000 \\
(-0.03)\end{array}$ \\
\hline Unemployment & $\begin{array}{l}-0.032 \\
(-1.32)\end{array}$ & $\begin{array}{l}-0.021 \\
(-0.83)\end{array}$ & $\begin{array}{l}-0.016 \\
(-0.62)\end{array}$ & $\begin{array}{l}-0.015 \\
(-0.59)\end{array}$ & $\begin{array}{l}-0.023 \\
(-1.05)\end{array}$ \\
\hline Piped Water & & $\begin{array}{l}0.011^{* *} \\
(2.41)\end{array}$ & $\begin{array}{l}0.011 \text { ** } \\
(2.33)\end{array}$ & $\begin{array}{l}0.010^{* *} \\
(2.18)\end{array}$ & $\begin{array}{l}0.010^{*} \\
(1.89)\end{array}$ \\
\hline Secondary School & & $\begin{array}{l}0.023 * * \\
(2.53)\end{array}$ & $\begin{array}{l}0.025^{* *} \\
(2.70)\end{array}$ & $\begin{array}{l}0.024 * * \\
(2.57)\end{array}$ & $\begin{array}{l}0.004 \\
(0.53)\end{array}$ \\
\hline Cabinet & & & $\begin{array}{l}0.178 \\
(0.74)\end{array}$ & $\begin{array}{l}0,159 \\
(0.65)\end{array}$ & $\begin{array}{l}0.099 \\
(0.49)\end{array}$ \\
\hline Opposition & & & $\begin{array}{l}-0.186 \\
(-0.71)\end{array}$ & $\begin{array}{l}-0.132 \\
(-0.44)\end{array}$ & $\begin{array}{l}-0.214 \\
(-0.82)\end{array}$ \\
\hline Kibaki & & & & $\begin{array}{l}0.040 \\
(0.36)\end{array}$ & $\begin{array}{l}0.193^{*} \\
(1.92)\end{array}$ \\
\hline Northeastern Province & & & & & \\
\hline East Province & & & & & $\begin{array}{l}-0.030 \\
(-0.08)\end{array}$ \\
\hline Coast Province & & & & & $\begin{array}{l}-3.932 * * * \\
(-10.24)\end{array}$ \\
\hline Nyanza Province & & & & & $\begin{array}{l}-6.420^{* * *} \\
(-9.43)\end{array}$ \\
\hline Western Province & & & & & $\begin{array}{l}-2.610^{* *} \\
(-2.13)\end{array}$ \\
\hline Rift Valley Province & & & & & $\begin{array}{l}-1.574 * * * \\
(-4.22)\end{array}$ \\
\hline Nairobi & & & & & $\begin{array}{l}-3.421 * * * \\
(-4.80)\end{array}$ \\
\hline Luhya & $\begin{array}{l}-3.074 * * * \\
(-8.77)\end{array}$ & $\begin{array}{l}-2.836 \text { *** } \\
(-8.06)\end{array}$ & $\begin{array}{l}-2.836^{* * *} \\
(-7.97)\end{array}$ & $\begin{array}{l}-2.798^{* * *} \\
(-7.77)\end{array}$ & $\begin{array}{l}-0.716 \\
(-0.61)\end{array}$ \\
\hline
\end{tabular}




\begin{tabular}{|c|c|c|c|c|c|}
\hline Explanatory variable & Model 1 & Model 2 & Model 3 & Model 4 & Model 5 \\
\hline Luo & $\begin{array}{l}-5.852^{* * *} \\
(-16.73)\end{array}$ & $\begin{array}{l}-5.440 * * * \\
(-14.93)\end{array}$ & $\begin{array}{l}-5.44 * * * \\
(-14.76)\end{array}$ & $\begin{array}{l}-5.499 * * * \\
(-13.95)\end{array}$ & $\begin{array}{l}-0.664 \\
(-1.12)\end{array}$ \\
\hline Kalenjin & $\begin{array}{l}-5.030^{* * *} \\
(-15.81)\end{array}$ & $\begin{array}{l}-4.600^{* * *} \\
(-13.62)\end{array}$ & $\begin{array}{l}-4.423 * * * \\
(-11.37)\end{array}$ & $\begin{array}{l}-4.393 * * * \\
(-10.99)\end{array}$ & $\begin{array}{l}-3.153^{* * *} \\
(-6.69)\end{array}$ \\
\hline Kamba & $\begin{array}{l}-3.898^{* * *} \\
(-8.87)\end{array}$ & $\begin{array}{l}-4.116^{* * *} \\
(-8.41)\end{array}$ & $\begin{array}{l}-4.166^{* * *} \\
(-8.47)\end{array}$ & $\begin{array}{l}-4.174 * * * \\
(-8.45)\end{array}$ & $\begin{array}{l}-4.299 * * * \\
(-8.90)\end{array}$ \\
\hline Kisii & $\begin{array}{l}-2.838^{* * *} \\
(-6.10)\end{array}$ & $\begin{array}{l}-2.679 * * * \\
(-5.69)\end{array}$ & $\begin{array}{l}-2.496 * * * \\
(-4.88)\end{array}$ & $\begin{array}{l}-2.378^{* * *} \\
(-3.82)\end{array}$ & $\begin{array}{l}4.410 * * * \\
(5.03)\end{array}$ \\
\hline Mji Kenda & $\begin{array}{l}-3.701 \text { *** } \\
(-9.30)\end{array}$ & $\begin{array}{l}-3.392^{* * *} \\
(-8.46)\end{array}$ & $\begin{array}{l}-3.328^{* * *} \\
(-8.16)\end{array}$ & $\begin{array}{l}-3.329 * * * \\
(-8.13)\end{array}$ & \\
\hline Other ethnic & $\begin{array}{l}-3.515^{* * *} \\
(-8.27)\end{array}$ & $\begin{array}{l}-2.861 \text { *** } \\
(-6.20)\end{array}$ & $\begin{array}{l}-2.728^{* * *} \\
(-5.57)\end{array}$ & $\begin{array}{l}-2.717 \text { *** } \\
(-5.50)\end{array}$ & $\begin{array}{l}-2.832 \\
(-6.76)\end{array}$ \\
\hline Adjusted $\mathrm{R}^{2}$ & 0.731 & 0.738 & 0.739 & 0.742 & 0.794 \\
\hline
\end{tabular}

Notes: See Table 4; GEMA is the omitted ethnic group. 
Table 6. Determinants of Constitutional Choice, Including Ethnic Population Shares

\begin{tabular}{|c|c|c|c|c|}
\hline Explanatory Variable & Model 1 & Model 2 & Model 3 & Model 4 \\
\hline Intercept & $\begin{array}{l}2.403 * * \\
(2.41)\end{array}$ & $\begin{array}{l}2.413 * * \\
(2.43)\end{array}$ & $\begin{array}{l}-1.182 \\
(-0.94)\end{array}$ & $\begin{array}{l}-0.938 \\
(-0.76)\end{array}$ \\
\hline Poverty & $\begin{array}{l}-0.019 \\
(-1.53)\end{array}$ & $\begin{array}{l}-0.026^{*} \\
(-2.00)\end{array}$ & $\begin{array}{l}-0.033^{* *} \\
(-2.71)\end{array}$ & $\begin{array}{l}-0.037^{* * *} \\
(-3.04)\end{array}$ \\
\hline Unemployment & $\begin{array}{l}-0.118^{* * *} \\
(-3.86)\end{array}$ & $\begin{array}{l}-0.125^{* * *} \\
(-4.03)\end{array}$ & $\begin{array}{l}-0.039 \\
(-1.06)\end{array}$ & $\begin{array}{l}-0.052 \\
(-1.41)\end{array}$ \\
\hline Piped Water & $\begin{array}{l}0.038^{* * *} \\
(5.46)\end{array}$ & $\begin{array}{l}0.034 * * * \\
(4.93)\end{array}$ & $\begin{array}{l}0.029 * * * \\
(3.93)\end{array}$ & $\begin{array}{l}0.028^{* * *} \\
(4.05)\end{array}$ \\
\hline Secondary School & $\begin{array}{l}-0.016^{*} \\
(-1.72)\end{array}$ & $\begin{array}{l}-0.019 * \\
(-2.05)\end{array}$ & $\begin{array}{l}0.040^{* * *} \\
(3.67)\end{array}$ & $\begin{array}{l}0.037^{* * *} \\
(3.39)\end{array}$ \\
\hline Cabinet & $\begin{array}{l}0.278 \\
(1.04)\end{array}$ & & $\begin{array}{l}0.723^{*} \\
(1.96)\end{array}$ & \\
\hline Opposition & $\begin{array}{l}-0.862 * * \\
(-2.67)\end{array}$ & & $\begin{array}{l}-0.520 \\
(-1.22)\end{array}$ & \\
\hline Kibaki & $\begin{array}{l}-0.437 * * * \\
(-4.43)\end{array}$ & $\begin{array}{l}-0.236^{* * *} \\
(-3.19)\end{array}$ & $\begin{array}{l}-0.241^{*} \\
(-1.85)\end{array}$ & $\begin{array}{l}-0.082 \\
(-0.87)\end{array}$ \\
\hline Ethnic share squared & $\begin{array}{l}0.551^{* *} \\
(2.61)\end{array}$ & $\begin{array}{l}0.616^{* * *} \\
(2.89)\end{array}$ & $\begin{array}{l}0.443^{*} \\
(1.71)\end{array}$ & $\begin{array}{l}0459 * \\
(1.77)\end{array}$ \\
\hline Northeastern Province & $\begin{array}{l}-0.447 \\
(-0.51)\end{array}$ & $\begin{array}{l}-0.371 \\
(-0.41)\end{array}$ & & \\
\hline East Province & $\begin{array}{l}-0.903 \\
(-1.59)\end{array}$ & $\begin{array}{l}-0.846 \\
(-1.45)\end{array}$ & & \\
\hline Coast Province & $\begin{array}{l}-2.839 * * * \\
(-4.49)\end{array}$ & $\begin{array}{l}-2.715^{* * *} \\
(-4.21)\end{array}$ & & \\
\hline Nyanza Province & $\begin{array}{l}-4.213^{* * *} \\
(-7.94)\end{array}$ & $\begin{array}{l}-4.183^{* * * *} \\
(-7.72)\end{array}$ & & \\
\hline Western Province & $\begin{array}{l}-2.339 * * * \\
(-4.27)\end{array}$ & $\begin{array}{l}-2.170^{* * *} \\
(-3.93)\end{array}$ & & \\
\hline Rift Valley Province & $\begin{array}{l}-3.809^{* * *} \\
(-7.63)\end{array}$ & $\begin{array}{l}-3.8536 * * * \\
(-7.55)\end{array}$ & & \\
\hline Nairobi & $\begin{array}{l}-5.411 \text { *** } \\
(-6.24)\end{array}$ & $\begin{array}{l}-4.873 * * * \\
(-5.64)\end{array}$ & & \\
\hline Adjusted $\mathrm{R}^{2}$ & 0.724 & 0.722 & 0.636 & 0.634 \\
\hline
\end{tabular}

Notes: See Table 4. 